\title{
«ТОЧКИ ВІДНОВЛЕННЯ» СТАЛОГО РОЗВИТКУ АГРАРНОГО ВИРОБНИЦТВА В УМОВАХ ЗРОСТАННЯ ВІДКРИТОСТІ НАЦІОНАЛЬНОЇ ЕКОНОМІКИ
}

\author{
Лагодієнко Наталія Володимирівна \\ кандидат економічних наук, доцент \\ Миколаївський національний аграрний університет (м. Миколаїв, Україна) \\ ORCID: 0000-0002-8472-1395 \\ besedina77@gmail.com
}

\begin{abstract}
В статті досліджуються аспекти існування «точки відновлення» сталого розвитку аграрного виробництва та розкрито особливості ї̈ визначення. Досліджено головні прояви порушення умов сталого розвитку аграрного виробництва України в умовах зростання відкритості національної економіки, їх наслідки та запропоновано «точки відновлення». Запропонований підхід дозволив виявити «точку відновлення», яка може послужити початком розгортання державної програми забезпечення сталого розвитку аграрного виробниитва України в умовах зростання відкритості національної економіки - це «відновлення поголів'я великої рогатої худоби».
\end{abstract}

Ключові слова: сталий розвиток, точки відновлення, аграрне виробництво, сільський розвиток, інвестиційна стратегія, відкритість національної економіки.

DOI: https://doi.org/10.32845/bsnau.2019.3.20

Постановка проблеми у загальному вигляді та їі зв'язок із важливими науковими чи практичними завданнями. 3 точки зору тактичного та стратегічного підходів, поточний стан національного аграрного виробництва задовольняє умову тактичної (короткострокову) економічної сталості при повному ігноруванні соціальної та екологічної. В стратегічній (довгостроковій) перспективі мають місце високі ризики економічної сталості аграрного виробництва через руйнування його соціальної та екологічної складової - гострий дефіцит кваліфікованих кадрів внаслідок знелюднення сільських територій, вітрова та водна ерозія ґрунтів, втрата їх родючості, замулення природних та штучних водойм, зневоднення та опустелення ареалів сільськогосподарського виробництва в Степовій агро-кліматичній зоні, втрата біологічного різноманіття через використання ГМО, формування стійких до засобів захисту рослин хвороб, бур'янів та комах внаслідок монокультуризму, збільшення залишків пестицидів у сільськогосподарській продукції внаслідок збільшення доз сильнодіючих отрутохімікатів тощо.

Наразі ссрормувався своєрідний аграрний цугцванг для української влади - оперативна системна та комплексна соціалізація й екологізація аграрного виробництва спричинить описаний вище спротив агрокомпаній та критичне погіршення міжнародного інвестиційного іміджу України, проте й залишення за нинішньою організацією агропродовольчого виробництва статусу кво, приведе в майбутньому до описаних катастрофічних наслідків, які в жодному разі не можна допускати. На нашу думку, виходом із даної ситуації є пошук так званих «точок відновлення» розвитку сталого аграрного виробництва в умовах відкритої національної економіки.

Аналіз останніх досліджень і публікацій, в яких започатковано розв'язання даної проблеми і на які спирається автор, виділення невирішених раніше частин загальної проблеми, котрим присвячується означена стаття. Теоретико-методичні засади української аграрної реформи, перспективні напрями розвитку галузей сільськогосподарського виробництва та ефрективного використання ресурсного потенціалу аграрної сфери економіки досліджували у свої працях багато вітчизняних вчених. Насамперед - це роботи Саблука П. Т., Гайдуцького П. І., Лупенка Ю. О., Меселя-Веселяка В. Я., Федорова М. М., Дієсперова В. С., Рябоконя В.

П., Бородіної О. М., Шубравської О. В., Мудрака Р.П. та ін. Важливий вклад у розвиток теорії та методології сталого розвитку, її адаптації до потреб вітчизняного аграрного виробництва зробили такі вітчизняні вчені як Аверкин М. Ф., Андрєєва Н. М., Балджи М. Д., Веклич О. О., Хлобистова Є. В., Піцура Я. С., Бурик З. М., Хвесик М. А., Лопатинський Ю. М., Копитко В. І., Ужва А. М., Курман Т. В. та ін. Проте, не зважаючи на достатньо глибоку наукову розробку досліджуваної тематики, наразі залишається багато невирішених питань, які викликають гостру дискусію як в науковій, так і практичній площині, зокрема - це питання існування «точки відновлення» сталого розвитку аграрного виробництва та розкриття особливостей її визначення.

Формулювання цілей статті (постановка завдання). Метою статті $€$ дослідження теоретичних аспектів щодо визначення «точки відновлення» сталого розвитку аграрного виробництва та обгрунтування практичних особливостей її визначення в умовах зростання відкритості національної економіки. У межах досягнення мети виокремлено наступні завдання: дослідити головні прояви порушення умов сталого розвитку аграрного виробництва України в умовах зростання відкритості національної економіки, їх наслідки та запропоновати «точки відновлення».

Виклад основного матеріалу дослідження 3 повним обґрунтуванням отриманих наукових результатів. Сталий розвиток аграрного виробництва має місце за умови гармонійного поєднання усіх його складових - економічної, соціальної та екологічної. На наше переконання одночасне забезпечення їх реалізації в нинішньому стані українського суспільства та національної економіки є складним завданНям.

«Точкою відновлення» ми називаємо конкретну кризову ситуацію або явище в певному секторі чи галузі економіки стосовно яких у суспільстві $є$ консенсус щодо нагальної необхідності її виправлення. В нашому випадку - це явища або процеси у вітчизняному агропродовольчому виробництві. Суспільний консенсус досягається шляхом тривалого формування відповідного інформаційного контенту за допомогою соціальної реклами, журналістських розслідувань, документальних фільмів та науково-популярних програм, громадсь-

Вісник Сумського національного аграрного університету 
ких 3MI, інтелектуальної спільноти із числа науковців та авторитетних громадських діячів тощо. 3 часом, сформована та достатньо кількісно висловлена колективна думка громадянського суспільства стосовно чітко артикульованої проблеми переходить у нову якість - реакцію державної адміністрації. При виникненні потенційної конфліктної ситуації із ринковими агентами чи їх групами, в тому числі із числа закордонних, які не зацікавлені у оголошених змінах, надійними аргументами державної адміністрації $€$ апелювання до: 1) думки демократичної більшості суспільства; 2) екологічного та безпекового законодавства ЄС, норми якого Україна зобов'язалася імплементувати в національне правове поле; 3) правил СОТ, які дозволяють національній державній адміністрації втручатися у формування та рух продовольчих потоків з метою захисту конкуренції і/або продовольчої безпеки.

Нами обґрунтовано головні прояви порушення умов сталого розвитку аграрного виробництва України в умовах зростання відкритості національної економіки, їх наслідки та «точки відновлення». Запропонований підхід дозволив виявити «точку відновлення», яка може послужити початком розгортання державної програми забезпечення сталого розвитку аграрного виробництва України в умовах зростання відкритості національної економіки - це «відновлення поголів'я великої рогатої худоби». Вона задовольняє три критичні умови: 1) відновлення поголів'я великої рогатої худоби однаково позитивно впливатиме на усі виміри сталого розвитку аграрного виробництва; 2) в українському суспільстві на усіх рівнях визрів консенсус стосовно того, що ситуація із фальсифікованою та неякісною молочною продукцією потребує негайного вирішення. Насамперед за допомогою збільшення обсягів виробництва якісної молочної сировини [1, 2, 3, 4, 5]; 3) приведення українського законодавства, яке регулює безпечність та якість молочної продукції, до вимог СОТ і ЄС.

Однією із головних причин скорочення поголів'я великої рогатої худоби та зменшення випуску відповідної продукції, є високі витрати виробництва в обох скотарських галузях та низькі доходи населення. В результаті дорога молочна продукція не знаходить належного збуту на внутрішньому ринку. А після втрати російського ринку молочної продукції, який не був компенсований ринком ЄС, стимули до відновлення поголів'я основного стада зникли.

Серед причин рекордного скорочення поголів'я корів та падіння обсягів виробництва молока в 2019p. (на 3,7\% порівняно із 2018p.) експерти також називають - незрозумілу ситуацію із запровадженням ринку землі, неповні виплати компенсацій існуючих програм державної підтримки, а також чутки про суттєве їх скорочення у 2020p. Через це деякі підприємства або повністю закрили молочний напрямок бізнесу, або максимально скоротили поголів'я за рахунок низькопродуктивної худоби, для акумуляції коштів [6].

Підвищення внутрішнього попиту на молочну продукції можна досягти, якщо нейтралізувати причини, які зумовили скорочення поголів'я корів - зменшити собівартість молочної сировини i/або підвищити рівень доходів населення. Якщо за нинішньої динаміки зростання економіки України друга умова досягається у достатньо віддаленій перспективі, то забезпечити скорочення витрат виробництва можна значно швидше.

Для виявлення характеру впливу факторів на рівень собівартості молока, використаємо відповідну регіональну статистику України. Проведений кореляційно-регресійний аналіз дав наступні результати: 1) коефіцієнт кореляції 0,642, отже, тіснота зв'язку - середня; 2) коефіцієнт детермінації - 0,412, отже, мінливість функції на 41,2\% визначається мінливістю вибраних факторів; 3) критерій Фішера: $F_{\phi}=$ $3,329, F_{K}=2,895 ; F_{\phi}>F_{\kappa}$, отже, нульова гіпотеза про відсутність зв'язку між показниками відкидається - модель адекватна реальності; 4) критерій Стьюдента: $t_{\phi}=4,756, t_{\kappa}=2,093$; $t_{\phi}>t_{\kappa}$, отже, нульова гіпотеза про незначущість коефіцієнта регресії відкидається - він є статистично значущим; 5) $\chi^{2}$-критерій Пірсона: $X^{2} \phi=8,041, X^{2}{ }_{k}=12,592 ; X^{2}{ }<X^{2}{ }_{\kappa}$, отже, в масиві регресорів мультиколінеарність відсутня; 7) рівняння регреciï: $Y=3358,986+0,617 x_{1}+1,9578 x_{2}-1,523 x_{3}-0,399 x_{4}+e$.

Для визначення вагової частки впливу кожного із факторів на мінливість результативної ознаки, проведено розкладання загальної варіації функції на фактори (табл. 1).

Розкладання загальної варіації собівартості молока на фактори

\begin{tabular}{|l|c|c|c|}
\hline \multicolumn{1}{|c|}{ Фактор } & Парний коефіцієнт кореляції, $r_{y x_{i}}$ & $\beta$-коефіціент, $\beta_{x_{i}}$ & $\begin{array}{c}\text { Процент, \% } \\
\left(r_{y x_{i}} \cdot \beta_{x_{i}} \cdot 100 \%\right)\end{array}$ \\
\hline Молочна продуктивність корів $\left(x_{1}\right)$ & 0,575809385 & 0,541427991 & 31,18 \\
\hline Посівна площа кормів $\left(x_{2}\right)$ & 0,254009102 & 0,074292887 & 1,89 \\
\hline Середньорічна кількість опадів $\left(x_{3}\right)$ & $-0,334589987$ & $-0,266489605$ & 8,92 \\
\hline Фонд споживання молока та молокопродуктів $\left(x_{4}\right)$ & 0,082793748 & $-0,093681321$ & $-0,78$ \\
\hline \multicolumn{2}{|c}{${ }^{*}$ розраховано автором за даними [8-10] }
\end{tabular}

Економетричне моделювання дозволило зробити ряд важливих висновків про чинники собівартості молока:

1) більше третини мінливості собівартості молока залежить від молочної продуктивності корів. Це вказує на значні резерви зниження витрат виробництва. В 2018р. середній річний удій молока в сільськогосподарських підприємствах склав 5945 кг на одну корову. Для порівняння - в ТОВ «Кищенці» Маньківського району Черкаської області в 2017р. корова-рекордистка породи голштин забезпечила річний удій молока на рівні 14800 кг [7]. Інший приклад - молоко-товарна ферма Укрлендфармінг у с. Підліснівка Сумського району
Сумської області. На фермі утримується 200 корів чорно-рябої породи голштин американської селекції. Надій на одну корову в 2018p. у середньому становив 9,3 тис. кг молока, а корови-рекордсменки забезпечили по 14-15 тис. кг молока екстра-класу і жирності 3,7\% [8];

2) частка посівних площ в структурі кормових угідь не чинить помітного впливу на мінливість функції - лише 1,89\%. По ідеї - збільшення посівів кормових культур мало б демонструвати прямо-пропорційний зв'язок із собівартістю молока: збільшуються виробничі витрати у частині кормовиробництва - зростає собівартість продукції. Проте таких зв'язок майже відсутній. Це може свідчити про те, що значна кількість кормів 
купується. Якщо це так, то відсутність прифермської кормової сівозміни підвищує ризики молочного бізнесу і робить його дуже чутливим до змін політики державної підтримки;

3) середньорічна кількість опадів майже на $9 \%$ впливає на собівартість продукції. Це дуже важливий висновок, який поряд із достатньою молочною продуктивністю, пояснює логіку територіальної спеціалізації сільськогосподарського виробництва. У регіонах із достатнім і надмірним рівнем зволоження (Північний Лісостеп, Полісся та Карпати) є можливість найменш затратного пасовищного утримання худоби тому що: 1) значна частина територій у даних зонах не придатні для вирощування традиційних високорентабельних польових культур через нерівний рельєф, велику кількість низинних ділянок (долин), що створює ідеальні умови для випасу; 2) через достатнє забезпечення вологою як посівні, так і дикоростучі кормові трави дають високі врожаї зеленої маси впродовж усього вегетаційного періоду;

4) зміна обсягів споживання молочних продуктів практично не впливає на собівартість молочної сировини. На нашу думку причиною досліджуваного зв'язку є те, що значна частина національного фонду споживання молочних продуктів (майже 50\%) формується за рахунок продукції особистих селянських господарств: 1) 25\% в структурі джерел молочної сировини переробних підприємств - це продукція особистих селянських господарств, 2) понад 60\% виробленого молока особисті селянські господарства продають у вигляді молочних продуктів (масло вершкове, кисломолочний сир, сметана, сире молоко) на організованих ринках; 3) у різні роки частка імпортної продукції у відповідному внутрішньому споживанні коливається від 2 до 3\%. Тому, наразі, зв'язок між зміною в обсягах споживання населенням молочних продуктів та собівартістю молока в сільськогосподарських підприємств - низький через наявність внутрішньогалузевої конкуренції, яке перешкоджає ефекту масштабу.

Для деталізація регіональної специфіки досліджуваних зв'язків, ми провели аналітичне групування у якому в якості групувальної ознаки - собівартість молока (табл. 2).

Таблиця 2

Аналітичне групування областей України за рівнем собівартості молока

в сільськогосподарських підприємствах у середньому за 2015-2018рр. *

\begin{tabular}{|c|c|c|c|c|c|}
\hline Область & $\begin{array}{c}\text { Собівартість молока, } \\
\text { грн. за } 1 \text { т. }\end{array}$ & $\begin{array}{c}\text { Молочна продуктивність, } \\
\text { кг на } 1 \text { гол. за рік }\end{array}$ & $\begin{array}{l}\text { Посівна площа } \\
\text { кормів, тис. га }\end{array}$ & \begin{tabular}{|c|} 
Середньорічна кількість \\
опадів, мм
\end{tabular} & $\begin{array}{c}\text { Фонд споживання молока та } \\
\text { молокопродуктів, тис. т }\end{array}$ \\
\hline Одеська & 3713 & 3433 & 42 & 400 & 458 \\
\hline Луганська & 4096 & 4443 & 23 & 450 & 330 \\
\hline Чернівецька & 4493 & 4897 & 49 & 775 & 221 \\
\hline Закарпатська & 4500 & 3620 & 43 & 1020 & 285 \\
\hline Львівська & 4509 & 4345 & 90 & 800 & 575 \\
\hline Житомирська & 4726 & 5044 & 170 & 585 & 276 \\
\hline Запорізька & 4832 & 4274 & 49 & 448 & 315 \\
\hline Івано-Франківська & 4990 & 4679 & 72 & 805 & 368 \\
\hline Cереднє по групі & 4482 & 4342 & 67 & 660 & 354 \\
\hline Сумська & 5191 & 5041 & 73 & 533 & 221 \\
\hline Донецька & 5216 & 5303 & 38 & 500 & 739 \\
\hline Чернігівська & 5334 & 4995 & 107 & 605 & 237 \\
\hline Дніпропетровська & 5405 & 4113 & 50 & 500 & 653 \\
\hline Рівненська & 5559 & 4396 & 90 & 650 & 238 \\
\hline Волинська & 5661 & 4294 & 79 & 595 & 225 \\
\hline Кіровоградська & 5738 & 5308 & 45 & 485 & 197 \\
\hline Миколаївська & 5848 & 4268 & 53 & 375 & 243 \\
\hline Вінницька & 5958 & 5369 & 121 & 555 & 331 \\
\hline Хмельницька & 5988 & 4462 & 102 & 570 & 292 \\
\hline Cереднє по групі & 5590 & 4755 & 76 & 537 & 337 \\
\hline Тернопільська & 6352 & 4847 & 50 & 560 & 251 \\
\hline Черкаська & 6360 & 5968 & 92 & 485 & 274 \\
\hline Полтавська & 6376 & 6054 & 108 & 530 & 311 \\
\hline Київська & 6590 & 6577 & 72 & 550 & 1004 \\
\hline Харківська & 6729 & 5660 & 83 & 525 & 615 \\
\hline Херсонська & 6954 & 4224 & 68 & 360 & 215 \\
\hline Середнє nо груni & 6560 & 5555 & 79 & 502 & 445 \\
\hline
\end{tabular}

Як бачимо, наше припущення виявилося вірним: в першій групі із найнижчою собівартістю молока - найвище значення показника середньомісячних опадів, а в групі за найвищою собівартістю молока - найнижче значення даного показника.

Такі висновки - важливий аргумент при обґрунтуванні національної програми розвитку молочного скотарства. На наше переконання, яке підтверджується результатами проведеного дослідження, національна програма розвитку моло- чного скотарства повинна бути спрямована на підтримку виробництва молока сільськогосподарськими підприємствами та фермерськими господарствами за територіальною ознакою. В групу областей, на які має поширюватися така програма, повинні входити: області Карпатського економічного регіону: Львівська; Івано-Франківська; Закарпатська; Чернівецька; області Поліської агрокліматичної зони: Чернігівська; Житомирська; Сумська; Рівненська; Волинська

На момент початку розрахунків, ми припускаємо, що 
в областях поза Карпатським економічним регіоном та Поліською агрокліматичної зоною збережеться фактичне поголів'я BPX. Далі, при обґрунтуванні розподілу планового поголів'я ВРX між областями виділених зон, необхідно виходити із їх ресурсних можливостей. Насамперед, земельних. Плановий приріст поголів'я ВРX визначено нами, як різниця розрахованого поголів'я - 5751 тис. гол. та фактичного поголів'я худоби поза виділеними зонами - 787,6 тис. гол.: 5751 - 787,6 $=4963,4$ (тис. гол.). Для того, щоб розподіл 4963,4 тис. голів ВРХ відповідав логіці територіального розміщення природноекономічних ресурсів, за базу порівняння ми взяли поголів'я відповідної худоби в 1990р. Далі ми визначили частки кожної області в структурі поголів' я ВРХ в 1990р. і використали їх для розподілу 4963,4 тис. гол. худоби - і як результат ресурсні можливості кожної області (1990р.) значно перевищують планову кількість поголів'я ВРX (2025р.) для кожної з них.

Враховуючи існуючу систему підтримки - дотація за утримання корів надається на безповоротній основі двічі на рік суб'єктам господарювання, які є юридичними особами, за кожну наявну станом на 1 січня та на 1 липня поточного року ідентифіковану та зареєстровану в установленому порядку корову в розмірі 750 гривень за одну голову. Тобто юридична особа за утримання однієї корови може отримати за рік 1500 гривень [11]. Дотація за молодняк надається на безповоротній основі фізичним особам за утримання ідентифікованого та зареєстрованого в установленому порядку молодняку великої рогатої худоби до 13-тимісячного віку, який народився в господарствах фізичних осіб у поточному році. Дотація за молодняк надається за кожні чотири місяці його утримання, зростаючи залежно від віку молодняку у розмірі: від 1 до 5 місяців - 300 гривень за голову; від 5 до 9 місяців - 700 гривень за голову; від 9 до 13 місяців - 1500 гривень за голову. Загальний обсяг дотації за молодняк не може перевищувати 2500 гривень із розрахунку на одну голову молодняку за період 12 місяців [11]. Ключовою проблемою відновлення та розвитку українського скотарства залишається невиконання державою взятих на себе зобов'язань по бюджетним виплатам на утримання основної, ремонтної та худоби на відгодівлі $[12,13]$. Реальна ж підтримка відродження та розвитку українського молочного скотарства коштуватиме державному бюджету не менше, ніж 10 млрд. грн. (табл. 3).

Таблиця 3

Вартість орієнтованих планових бюджетних дотацій на розвиток молочного скотарства в сільськогосподарських підприємствах та фермерських господарствах

Карпатського економічного регіону та Поліської агрокліматичної зони, млн. грн. ${ }^{*}$

\begin{tabular}{|l|c|c|c|c|c|}
\hline \multirow{2}{*}{ Область } & \multicolumn{2}{|c|}{ Поголів'я ВРХ станом на початок 2025р., тис. гол. } & \multicolumn{2}{c|}{ Сума дотацій, млн. грн. } & Всього, \\
\cline { 2 - 5 } & корови & худоба на вирощуванні та відгодівлі & на корови & на худобу на вирощуванні та відгодівлі & млн. грн. \\
\hline Львівська & 302,9 & 401,5 & 454,4 & 1003,8 & 7458,1 \\
\hline Івано-Франківська & 160,9 & 213,3 & 241,4 & 533,3 & 774,6 \\
\hline Закарпатська & 97,5 & 129,2 & 146,3 & 323,0 & 469,3 \\
\hline Чернівецька & 124,0 & 164,4 & 186,0 & 411,0 & 597,0 \\
\hline Чернігівська & 396,6 & 525,7 & 594,9 & 1314,3 & 1909,2 \\
\hline Житомирська & 319,3 & 423,2 & 479,0 & 1058,0 & 1537,0 \\
\hline Сумська & 257,0 & 340,6 & 385,5 & 851,5 & 1237,0 \\
\hline Рівненська & 224,1 & 297,0 & 336,2 & 742,5 & 1078,7 \\
\hline Волинська & 252,2 & 334,3 & 378,3 & 835,8 & 1214,1 \\
\hline Разом & $\mathbf{2 1 3 4 , 5}$ & $\mathbf{2 8 2 9 , 2}$ & $\mathbf{3 2 0 1 , 8}$ & $\mathbf{7 0 7 3 , 0}$ & $\mathbf{1 0 2 7 4 , 8}$ \\
\hline
\end{tabular}

Висновки з даного дослідження і перспективи подальших розвідок у даному напрямку. Конструктивна логіка «точок відновлення» полягає в тому, що вони розгортаються м'яко - не раптово і відразу усі, а поступово та з інформаційною підготовкою впродовж певного часового інтервалу. Це дозволить не розпорошувати, а сконцентровувати обмежені кадрові, організаційні та фінансові ресурси на формуванні колективної громадської думки і подоланні опору незацікавлених у змінах ринкових агентів чи їх груп. А також привчить усіх стейкхолдерів вітчизняного продовольчого ринку до послідовності української влади та її невідворотному курсі на формування екологічно безпечного та соціально справедливого агропродовольчого виробництва. Це зумовить кумулятивний управлінський ефект - успіхи на стадії перших «точок відновлення» послаблять потенційний опір незацікавлених у змінах ринкових агентів чи їх груп на наступних «точках відновлення».
В процесі дослідження отримано витрати, які дозволять досягти гармонізації трьох складових сталого розвитку аграрного виробництва в умовах зростання відкритості національної економіки:

- економічної. Завдяки диверсифікації ризиків аграрного виробництва через розвиток галузей виробництва, зорієнтованих на забезпечення внутрішнього ринку. А також забезпечення ресурсних умов відтворення родючості ґрунтів та отримання стабільних врожаїв - за рахунок значного збільшення виробництва та використання органічних добрив;

- соціальної. Завдяки підвищенню зайнятості на сільських територіях та забезпеченню продовольчої безпеки;

- екологічної. Завдяки збільшенню використання ґрунтозахисних технологій через зростання площ посівів кормових культур, пасовищ та сінокосів. Збереження та відтворення родючості ґрунтів внаслідок збільшення обсягів використання органічних добрив.

\section{Список використаної літератури:}

1. Мудрак Р.П., Цимбалюк Ю.А., Корман І.І. Маркетинговий аналіз національного ринку молока та молочної продукції. Актуальні проблеми економіки, 2016, №8(182), С. 69-84.

2. Головне управління Держпродспоживслужби у Вінницькій області. Увага: виявлено фральсифрікат молочної продукції! [Електронний ресурc]. URL: https://www.vingudpss.gov.ua/news/uvaga-viyavleno-falsifikat-molochnoyi-produkciyi 
3. Експерти: Близько 70\% вершкового масла - фальсифікат [Електронний ресурс]. Укрінформ, 24.01.2019. URL: https://www.ukrinform.ua/rubric-economy/2626139-eksperti-blizko-70-verskovogo-masla-falsifikat.html

4. Мудрак Р. П., Лагодієнко В. В. Агроінфляція та індекс споживчих цін на продо-вольчі товари: порівняльний аналіз «Україна - ЄС». Економіка України, 2018, № 1.С. 28-39.

5. Лагодієнко В.В. Концептуальна модель розвитку регіонального агропромислового виробництва. Глобальні та національні проблеми економіки. 2015. № 8. С. 1259-1262.

6. Експерти пояснили, що призвело до рекордного падіння виробництва молока в Україні [Електронний ресурс]. Укрінформ, 22.01.2020. URL: https://www.ukrinform.ua/rubric-economy/2860664-eksperti-poasnili-so-prizvelo-do-rekordnogo-padinnavirobnictva-moloka-v-ukraini.html

7. В Укрлендфрармінг Бахматюка заявили про рекордні надої молока [Електронний ресурс]. УHIAH, 07.11.2018. URL: https://www.unian.ua/economics/agro/10328778-ukrlendfarming-bahmatyuka-zayavili-pro-rekordni-nadoji-moloka.html

8. Статистичний збірник «Сільське господарство України 2018». К.: Державна служба статистики України, 2019. 235 с.

9. Середні ціни продукції сільського господарства, реалізованої підпри-ємствами (1996-2018) [Електронний ресурс]. URL: http://www.ukrstat.gov.ua/operativ/ operativ2006/sg/sg_rik/sg_u/scr_sp_u.html

10. Рівень рентабельності виробництва продукції сільського господарства в сільськогосподарських підприємствах (1990-2018) [Електронний ресурc]. URL: http://www.ukrstat.gov.ua/operativ/operativ2006/sg/sg_rik/sg_u/rrv_sgp_u.html

11. За утримання корів та молодняку BPX - державна підтримка. Урядовий портал [Електронний ресypc]. URL: https://www.kmu.gov.ua/news/za-utrimannya-koriv-ta-molodnyaku-vrh-derzhavna-pidtrimka

12. Бюджет України на 2020 рік для агросектору - чотири сюрпризи [Електронний ресурc]. AgroPolit. URL: https://agropolit.com/spetsproekty/630-byudjet-ukrayini-na-2020-rik-dlya-agrosetkoru--chotiri-syurprizi

13. Ужва А. М. Комплексна діагностика економічної складової сталого розвитку сільськогосподарських підприємств у конкурентному середовищі // Економічний аналіз. 2017. Том 27. № 3. С. 228-235 (індексується в науково-метричних базах: Index Copernicus, WorldCat, Windows Live Academic, ResearchBible, Open Academic Journals Index) (0,53 друк. арк.).

14. Михайлова Л. І., Турчіна С. Г., Данько Ю. І. Міжнародний бізнес: навч. посіб //Суми: Вид-во Козацький вал ВАТ Сумська обласна друкарня. - 2009.

Lagodiienko N.V., PhD, Associate professor, Mykolaiv national agrarian university (Mykolaiv, Ukraine)

"Recovery points" of sustainable development of agricultural production in conditions of increasing openness of the national economy.

The article explores aspects of the existence of a "point of recovery" of sustainable development of agricultural production and reveals the features of its definition. The main manifestations of violations of the conditions of sustainable development of agrarian production of Ukraine in the conditions of increasing openness of the national economy, their consequences and the "points of recovery" are investigated. The proposed approach revealed the "recovery point" that could be the beginning of the launch of the state program for sustainable development of agrarian production of Ukraine.

The main manifestations of violations of the conditions of sustainable development of agrarian production of Ukraine under conditions of increasing openness of the national economy, their consequences and the "point of recovery" are substantiated. The proposed approach revealed the "recovery point" that could be the beginning of the launch of the state program for sustainable development of agrarian production of Ukraine in the conditions of increasing openness of the national economy - the "recovery of cattle". It satisfies three critical conditions: 1) the rebuilding of the cattle population will equally positively affect all dimensions of sustainable agricultural development; 2) consensus has emerged at all levels in Ukrainian society that the situation with counterfeit and substandard dairy products needs immediate resolution. First of all, by increasing the production of quality dairy raw materials; 3) bringing Ukrainian legislation governing the safety and quality of dairy products to WTO and EU requirements.

In the course of the research the expenses were obtained, which will allow to achieve harmonization of three components of sustainable development of agrarian production in conditions of increasing openness of the national economy:

- economic. Due to the diversification of the risks of agricultural production through the development of industries focused on ensuring the internal market. And also to provide resource conditions for reproduction of soil fertility and obtaining stable yields - due to a significant increase in production and use of organic fertilizers;

- social. Due to increased employment in rural areas and food security;

- environmental. Due to the increase in the use of soil protection technologies due to the growing area of crops of forage crops, pastures and hayfields. Preservation and restoration of soil fertility due to increased use of organic fertilizers.

Key words: sustainable development, recovery points, agricultural production, rural development, investment strategy, openness of the national economy.

Дата надходження до редакції: 30.08.2019 р. 